\title{
Effect of volcanic ash on GHG production rates and soil properties in a drained peat soil compared to wood ash
}

\author{
Marja Maljanen ${ }^{a^{*}}$, MaArit LiImatainen ${ }^{a}$, BJarni D. Sigurdsson ${ }^{B}$ \\ a) University of Eastern Finland, Department of Environmental Science, P.O. Box 1627, FI-70211, Kuopio, Finland \\ marja.maljanen@uef.fi, *corresponding author,Tel.+358500137666,maarit.liimatainen@uef.fi \\ b) Agricultural University of Iceland, Hvanneyri, IS-311, Borgarnes, Iceland, bjarni@lbhi.is
}

\section{INTRODUCTION}

Past volcanic eruptions in Iceland have sometimes led to long-distance distribution of fine volcanic tephra (volcanic ash). Evidence for volcanic ash from, for example, the ca. 4250 BP eruption in Hekla (H4) and the 17831784 AD Laki eruption in southern Iceland has been found in wetlands at Svalbard (Kekonen et al. 2005), Scotland (Charman et al. 1995) and Scandinavia (Thorarinsson 1981). Basaltic volcanic ash contains several compounds, e.g. mixed sulphates, ammonium $\left(\mathrm{NH}_{4}^{+}\right)$and nitrate $\left(\mathrm{NO}_{3}^{-}\right)$(Ayris and Delmelle 2012), all of which have the potential to affect various soil processes, such as $\mathrm{N}$ cycling and greenhouse gas (GHG) production. Such direct effects of long distance volcanic ash transport have, however, been little studied so far.

The Eyjafjallajökull volcano eruption started in Iceland in March, 2010. A major outbreak of the central crater under the covering ice cap started on 14 April and continued until 24 May, ejecting a very large amount of gases and fine ash into the atmosphere. This ash contained mainly silicon dioxide, but also other compounds including sulphates (O’Dowd et al. 2012). This eruption gave us an opportunity to study the fresh volcanic ash and its effects on soil properties. Because this volcanic ash was alkaline, it could increase soil $\mathrm{pH}$ and affect the microbiological processes behind GHG emissions in a similar way to that suggested for wood ash (Maljanen et al. 2014, Klemedtsson et al. 2010). We used fresh volcanic ash from the Eyjafjallajökull volcano in a laboratory experiment conducted on samples of drained peat soil from western Finland that were also used for studying the effects of wood ash recycling from bioenergy power plants (Maljanen et al. 2014). The aim of this study was to test whether this volcanic ash affected GHG production rates in drained peat soil in our laboratory incubation experiments and to compare the results with wood ash.

\section{MATERIALS AND METHODS}

Fresh volcanic ash from the Eyjafjallajökull volcano was sampled April 15, 2010, by the staff of the Agricultural University of Iceland. The wood ash used as a reference was commercial granulated wood ash (Ecolan, Viitasaari, Finland). Peat soil samples for the incubation experiments were taken from a forested peatland

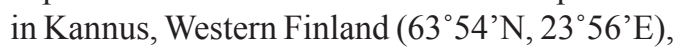
drained in the 1960's. The peat is acidic and rather well decomposed, $\mathrm{H} 8$, according to the von Post scale. More details about the site can be found in Maljanen et al. (2014).

In the incubation experiments $25 \mathrm{~g}$ of fresh manually homogenized peat soil sampled below the litter layer were weighed into $550 \mathrm{ml}$ flasks. Five control flasks (C) contained only peat but in ash treatments $(n=5) 1.6 \mathrm{~g}$ of volcanic ash (VA) or granulated wood ash (WA) was mixed in the peat, corresponding to a $5000 \mathrm{~kg} \mathrm{ha}^{-1}$ ash deposition. During the two-week incubation time flasks were closed with aluminium foil 




Figure 1. Production rates of (A) nitrous oxide $\left(\mathrm{N}_{2} \mathrm{O}\right)$, (B) carbon dioxide $\left(\mathrm{CO}_{2}\right)$ and $(\mathrm{C})$ methane $\left(\mathrm{CH}_{4}\right)$ in untreated peat soil (control) or in soils affected by addition of wood ash or volcanic ash two days after addition of ash (wk 0) and after 1 and 2 weeks of incubation. Nitrous oxide production rate was also studied after addition of nitrification inhibitor, 2.5\% acetylene. Negative bars (C) indicate net consumption of $\mathrm{CH}_{4}$. Error bars show the standard error of mean $(n=5)$.

and they were incubated in the dark at $+15^{\circ} \mathrm{C}$. Gas sampling from the flask was repeated four times (Figure 1). In the beginning, after one week and again after two weeks, the flasks were closed with rubber septa and $20 \mathrm{ml}$ gas samples were taken repeatedly (after 1, 2, 4 and $6 \mathrm{~h}$ ) from their headspace and then opened again. After the second week sampling, $2.5 \%$ of acetylene $\left(\mathrm{C}_{2} \mathrm{H}_{2}\right)$ was added into the headspace and gas sampling was repeated as earlier. The aim of adding $\mathrm{C}_{2} \mathrm{H}_{2}$ as nitrification inhibitor (Klemedtsson et al. 1988) was to study the contribution of nitrification to $\mathrm{N}_{2} \mathrm{O}$ production with and without ash application.

Gas samples were analysed for $\mathrm{N}_{2} \mathrm{O}, \mathrm{CO}_{2}$ and $\mathrm{CH}_{4}$ with a gas chromatograph (Agilent 6890N Network GC System, Agilent Technologies, USA) coupled to an autosampler (Gilson 222XL, Gilson Company Inc., USA). The production rates of the gases were calculated from the linear change of the concentration in the headspace. Soil $\mathrm{pH}$ and electrical conductivity (EC) were determined after the incubation experiment. Concentrations of nitrate $\left(\mathrm{NO}_{3}^{-}\right)$, nitrite $\left(\mathrm{NO}_{2}^{-}\right)$, chloride $\left(\mathrm{Cl}^{-}\right)$, sulphate $\left(\mathrm{SO}_{4}^{2-}\right)$ and ammonium $\left(\mathrm{NH}_{4}^{+}\right)$in peat and ash samples were measured using an ion chromatograph (DX 120, Dionex Corporation, USA), or by spectrophotometer (Ultrospec 3000 Pro, Biochrom, UK). The contents of other elements (Table 1) were analysed with inductively coupled plasma atomic emission spectroscopy (ICP-AES). A

Table 1. The total amount of elements $\left(\mathrm{mg} \mathrm{g}^{-1}\right)$ in the ash and the amount of exchangeable ions (mg g $\mathrm{m}^{-1} \mathrm{dry}$ ash) extracted from the ash using acidic ammonium acetate. "nd" stands for "not determined".

\begin{tabular}{lccccccccccccccccc}
\hline & Al & $\mathbf{C a}$ & $\mathbf{F e}$ & $\mathbf{K}$ & $\mathbf{M g}$ & $\mathbf{M n}$ & $\mathbf{N a}$ & $\mathbf{P}$ & $\mathbf{P b}$ & $\mathbf{S}$ & $\mathbf{Z n}$ & $\mathbf{B}$ & $\mathbf{C d}$ & $\mathbf{C r}$ & $\mathbf{C u}$ & $\mathbf{M o}$ & $\mathbf{N i}$ \\
\hline Total elements: & & & & & & & & & & & & & & & & \\
Volcanic ash & 6.0 & 4.1 & 18 & 0.6 & 6.7 & 0.3 & 2.6 & 0.3 & $<0.1$ & 0.4 & 0.0 & 3.7 & $<0.1$ & 13 & 7.0 & $<0.1$ & 29 \\
Wood ash & 37 & 180 & 25 & 25 & 15 & 5.8 & 9.6 & 9.9 & 0.2 & 20 & 1.8 & 220 & 8.7 & 79 & 130 & 3.4 & 33 \\
Exchangeable elements: & & & & & & & & & & & & & & \\
Volcanic ash & 0.10 & 1.90 & 0.24 & 0.32 & 0.11 & 0.04 & 0.67 & 0.02 & nd & 0.13 & nd & nd & nd & nd & nd & nd & nd \\
Wood ash & 0.20 & 83.7 & 0.02 & 13.7 & 5.91 & 0.30 & 5.35 & 0.08 & nd & 10.0 & nd & nd & nd & nd & nd & nd & nd \\
\hline
\end{tabular}


more detailed description of analytical methods used in the present study can be found in Maljanen et al. (2014) and Liimatainen et al. (2014).

Differences between treatments were tested with SPSS (IBM SPSS statistics 19) with oneway ANOVA $\left(\mathrm{NO}_{3}^{-}\right.$and $\mathrm{NH}_{4}^{+}$concentrations) or a non-parametric Kruskal Wallis test (gas production rates). Tukey's test or Mann-Whitney U-tests were used for pairwise comparisons when significant overall differences were found.

\section{RESULTS AND DISCUSSION}

The concentration of both total and soluble elements was lower in VA than in WA, except for $(\mathrm{Fe})$ which had higher total concentrations in WA but was still more soluble in VA (Table 1). Both ash types were alkaline, increasing soil $\mathrm{pH}$ slightly during the incubation (Table 2). Electrical conductivity (EC) was increased 5-fold in the WA treatment compared to $\mathrm{C}$, while the increase in EC was only minor with VA, confirming that there were fewer soluble ions in the VA than in the WA. The concentrations of $\mathrm{SO}_{4}^{2-}$ and $\mathrm{Cl}^{-}$were not much affected by VA in the incubated soil, while the WA treatment led to 20 times higher concentrations (Table 2). Volcanic ash extracted without peat contained more $\mathrm{NH}_{4}^{+}$than wood ash, but in peat extracts after incubation the amount of $\mathrm{NH}_{4}^{+}$in VA was lower than in WA or $\mathrm{C}(\mathrm{p}=0.046$ and $\mathrm{p}<0.01)$ (Table 2). The concentration of $\mathrm{NO}_{3}{ }^{-} \mathrm{N}$ in WA was reduced $(\mathrm{p}<0.01)$ by a similar amount as the increase in $\mathrm{NH}_{4}^{+}-\mathrm{N}$ in WA. This may indicate some VA-mediated stimulation of microbial $\mathrm{NH}_{4}^{+}$uptake.
The nitrous oxide production rate from the peat soil with VA was, however, similar to the untreated control, but WA significantly $(\mathrm{p}=$ 0.008 ) reduced $\mathrm{N}_{2} \mathrm{O}$ production (Figure 1). The $\mathrm{N}_{2} \mathrm{O}$ production rates did not change during the two-week incubation period. Acetylene treatment inhibited $\mathrm{N}_{2} \mathrm{O}$ production $80 \%$ in $\mathrm{C}$ soil as well as in VA soil. In WA treatments there was no additional effect with $\mathrm{C}_{2} \mathrm{H}_{2}$. The acetylene experiment shows that in this peat soil nitrification was probably the main source of $\mathrm{N}_{2} \mathrm{O}$, since acetylene inhibited $\mathrm{N}_{2} \mathrm{O}$ production. Wood ash also blocked $\mathrm{N}_{2} \mathrm{O}$ production but VA did not. The lower inhibitory effect of VA than WA here was probably associated with the extractable ion content of the ash rather than a change in $\mathrm{pH}$ as suggested by Klemedtsson et al. (2010). Our previous findings showed that addition of ions (sulphate) can cause a decline in nitrification and $\mathrm{N}_{2} \mathrm{O}$ production as similar to that in wood ash (see Liimatainen et al. 2014).

Drained peat soils emit $\mathrm{CO}_{2}$ as a result of a higher peat decomposition rate than in pristine peat (Maljanen et al. 2010). In our experiment the aerobic peat soil emitted $\mathrm{CO}_{2}$ in all treatments (Figure 1). The production rates during the first sampling were significantly lower in peat with VA than in $\mathrm{C}$ or WA $(\mathrm{p}=0.032)$. After a one or two week incubation the difference was not significant. With VA the $\mathrm{CO}_{2}$ production rate seemed to increase with time, indicating that in the beginning there could be some inhibiting effects in the VA on soil respiration which recovered within two weeks. The limited incubation time did not allow us to see if there were any long-term effects of VA. Klemedtsson

Table 2. Soil physical and chemical properties measured from the ash extracts $(\mathrm{VA}=$ volcanic ash, WA $=$ wood ash) without peat and from peat after incubation experiment. Results are given in $\mu \mathrm{g} \mathrm{g}^{-1}$ (dry soil) \pm standard deviation $(\mathrm{n}=5)$. * shows statistical difference from the control (one-way ANOVA, $\mathrm{p}<0.05$ ).

\begin{tabular}{|c|c|c|c|c|c|c|c|}
\hline Treatment & $\underset{\left(\mathbf{H}_{2} \mathbf{O H}\right)}{\mathbf{p H}}$ & $\begin{array}{c}\mathbf{E C} \\
\left(\mu \mathrm{S} \mathrm{cm}^{-1}\right)\end{array}$ & $\begin{array}{l}\mathrm{NO}_{3}^{-}-\mathrm{N} \\
\left(\mu \mathrm{g} \mathrm{g}^{-1}\right)\end{array}$ & $\begin{array}{l}\mathrm{NO}_{2}^{-}-\mathrm{N} \\
\left(\mu \mathrm{g} \mathrm{g}^{-1}\right)\end{array}$ & $\begin{array}{l}\mathrm{NH}_{4}^{+}-\mathbf{N} \\
\left(\mu \mathrm{g} \mathrm{g}^{-1}\right)\end{array}$ & $\underset{\left(\mu \mathrm{g} \mathrm{g}^{-1}\right)}{\mathrm{Cl}^{-}}$ & $\underset{\left(\mu \mathbf{g ~ g}^{-1}\right)}{\mathrm{SO}^{-}}$ \\
\hline VA & 7.8 & $61 \pm 14$ & $0.2 \pm 0.4$ & $<0.1$ & $18 \pm 25$ & $540 \pm 25$ & $1100 \pm 82$ \\
\hline WA & 8.8 & $1100 \pm 23$ & $7.5 \pm 8.6$ & $1.4 \pm 2.4$ & $2.5 \pm 1.1$ & $20000 \pm 330$ & $65000 \pm 4400$ \\
\hline Control peat & 3.2 & $280 \pm 16$ & $71 \pm 1$ & $<0.1$ & $88 \pm 5$ & $64 \pm 48$ & $250 \pm 95$ \\
\hline Peat with VA & $3.5^{*}$ & $290 \pm 50$ & $70 \pm 1$ & $<0.1$ & $73 \pm 4^{*}$ & $73 \pm 4$ & $380 \pm 55$ \\
\hline Peat with WA & $3.6^{*}$ & $1400 \pm 60^{*}$ & $55 \pm 4^{*}$ & $<0.1$ & $96 \pm 4^{*}$ & $1500 \pm 120^{*}$ & $5000 \pm 330^{*}$ \\
\hline
\end{tabular}


et al. (2010) have reported reduction in $\mathrm{CO}_{2}$ emissions in the field, even some years after WA treatment, whereas the study by Maljanen et al. (2014), for example, shows contrasting results.

Drained peat soils usually have a low $\mathrm{CH}_{4}$ production rate or the methane oxidizing bacteria in soil consume more $\mathrm{CH}_{4}$ than is produced in the deeper peat (Maljanen et al. 2010). Here the studied soil also had a very low $\mathrm{CH}_{4}$ production rate and after a two week incubation all treatments showed net methane uptake, indicating a higher net $\mathrm{CH}_{4}$ consumption than production rate in the peat (Figure 1). Neither VA nor WA significantly affected net $\mathrm{CH}_{4}$ production or consumption rates. This was in agreement with our previous findings with wood ash (Maljanen et al. 2014), but contrasting results have been reported (Klemedtsson et al. 2010).

The amounts of volcanic ash supplied to the incubated peat soils in this experiment were rather high for what could be expected to reach Finland naturally from a volcanic eruption. However, it corresponded to the common dose of wood ash fertilization in peatland forestry there $\left(5000 \mathrm{~kg}\right.$ ash $\left.\mathrm{ha}^{-1}\right)$. The amounts were, however, far less than can be expected to be deposited closer to the active volcanos during a major tephra-producing eruption. In Iceland the majority of the lowland peatlands are drained and they therefore are potential sources of $\mathrm{CO}_{2}$ and $\mathrm{N}_{2} \mathrm{O}$ (Maljanen et al. 2010). There it is a possibility that the volcanic ash deposition could affect the microbiology in peat more strongly than seen in the present study and therefore also have relatively stronger effects on their GHG emissions. This warrants some further studies.

\section{ACKNOWLEDGEMENTS}

We thank Rannveig Anna Guicharnaud for sampling the fresh volcanic ash in Iceland, Seppo Vihanta for sampling the peat and Dr Terry G. Lacy for checking the English.

\section{REFERENCES}

Ayris PM \& Delmelle P 2012. The immediate environmental effects of tephra emission. Bulletin of Volcanology 74, 1905-1936.
Charman DJ, West S, Kelly A \& Grattan J 1995. Environmental change and tephra deposition: The strath of Kildonan, Northern Scotland. Journal of Archaeological Science 22, 799-809.

Kekonen T, Moore J, Perämäki P \& Martma T 2005. The Icelandic Laki volcanic tephra layer in the Lomonosovfonna ice core, Svalbard. Polar Research 24, 33-40.

Klemedtsson L, Svensson BH \& Rosswall T 1988. A method to distinguish between nitrification and denitrification as sources of nitrous oxide in soil. Biology and Fertility of Soils 6, 112-199.

Klemedtsson L, Ernfors M, Björk RG, Weslien P, Rütting T \& Crill P 2010. Reduction of greenhouse gas emissions by wood ash application to a Picea abies (L.) Karst. forest on a drained organic soil. European Journal of Soil Science 61, 734-744.

Liimatainen M, Martikainen PJ \& Maljanen M 2014. Why granulated wood ash decreases $\mathrm{N}_{2} \mathrm{O}$ production in boreal acidic peat soil? Soil Biology and Biochemistry 79, 140-148.

Maljanen M, Liimatainen M, Hytönen $\mathbf{J}$ \& Martikainen PJ 2014. The effect of wood ash fertilization on soil properties and greenhouse gas (GHG) emissions in boreal peatland forests. Boreal Environment Research 19, 295-309.

Maljanen M, Sigurdsson BD, Guðmundsson J, Óskarsson H, Huttunen JT \& Martikainen PJ 2010. Greenhouse gas balances of managed peatlands in the Nordic countries - present knowledge and gaps. Biogeosciences 7, 27112738.

O'Dowd C, Ceburnis D, Ovadnevaite J, Martucci G, Bialek J, Monahan C, Berresheim H, Vaishya A, Grigas T, Jennings SG, McVeigh P, Varghese S, Flanagan R, Martin D, Moran E, Lambkin K, Semmler T, Perrino C \& McGrath R 2012. The Eyjafjallajökull ash plume - Part I: Physical, chemical and optical characteristics. Atmospheric Environment 48, 129-142.

Thorarinsson S 1981. Greetings from Iceland: Ash-falls and volcanic aerosols in Scandinavia. Geografiska Annaler. Series A, Physical Geography 63, 109-118.

Manuscript received 11 December 2014 Accepted 6 February 2015 